\title{
EFFECT OF DIFFERENT LEVELS OF HONEY ON PHYSIOLOGI- CAL, GROWTH AND CARCASS TRAITS OF BROILER CHICKENS DURING DRY SEASON
}

\author{
Oyegunle Emmanuel OKE ${ }^{1,2}$, Faith O. SORUNGBE ${ }^{1}$, Monsuru Oladimeji ABIOJA ${ }^{1}$, Oluwad- \\ amilola OYETUNJI ${ }^{1}$, Anuoluwapo Olamide ONABAJO ${ }^{1}$
}

Received January 13, 2016; accepted May 17, 2016. Delo je prispelo 13. januarja 2016, sprejeto 17. maja 2016.

\begin{abstract}
Effect of different levels of honey on physiological, growth and carcass traits of broiler chickens during dry season

The objective of this trial was to investigate the effect of different levels of honey in drinking water on the responses of broiler chickens during dry season in hot humid tropics. Three hundred Oba Marshall broiler chicks were used for this study. The day-old chicks were randomly assigned to five treatment groups with each treatment having four replicates of 15 birds. The first 4 treatment groups were daily supplied drinking water without honey $(0 \mathrm{H})$, with $20 \mathrm{ml}(20 \mathrm{H}), 40 \mathrm{ml}(40 \mathrm{H})$ and 60 $\mathrm{ml}(60 \mathrm{H})$ of honey per liter of water. The fifth group received drinking water supplemented with $500 \mathrm{mg}$ vitamin $\mathrm{C}$ per liter of water (C). Records on daily weight gain (WG) and feed intake (FI) were taken. Feed conversion ratio (FCR) was calculated as the ratio of gain to feed consumed. The supplementation of honey in the drinking water for broiler chickens in $60 \mathrm{H}$ during hot dry season in the hot humid tropics improved some stress indices, body weight gain and relative spleen weight.

Key words: poultry; broiler chickens; animal nutrition; honey; growth; physiological traits; carcass traits; hot dry season
\end{abstract}

\section{INTRODUCTION}

Broiler chicken production plays a vital role in food security for the fast increasing human population in $\mathrm{Ni}$ geria due to the short production cycle, high feed efficiency and growth rate of the birds. The birds are however faced with the challenges of coping with the ever changing elements of weather, especially the ambient temperature typically during growing-finishing phase in the tropics. This is partly due to the fact that the tropics and sub-tropics are faced with the challenge of high am-
Učinek dodajanja različnih količin medu na fiziološke, rastne in klavne lastnosti pitovnih piščancev $v$ sušnih razmerah

Cilj raziskave je bil proučiti vpliv dodajanja različnih količin medu v pitno vodo pitovnih piščancev med vročim in suhim obdobjem v vročih in vlažnih tropih. Za to študijo smo uporabili 300 pitovnih piščancev provenience Oba Marshall. Enodnevni piščanci so bili naključno razporejeni v pet poskusnih skupin, s štirimi ponovitvami s po 15 piščanci v vsaki skupini. V prvih štirih skupinah so piščanci dobivali pitno vodo brez medu $(0 \mathrm{H})$, z $20 \mathrm{ml}(20 \mathrm{H}), 40 \mathrm{ml}(40 \mathrm{H})$ in $60 \mathrm{ml}(60 \mathrm{H})$ medu na liter vode. Peta skupina je dobivala pitno vodo, dopolnjeno s $500 \mathrm{mg}$ vitamina $\mathrm{C}$ na liter vode $(\mathrm{C})$. Merili smo dnevne priraste (WG) in količino zaužite krme (FI). Izkoriščanje krme (FCR) smo izračunali kot razmerje med prirastom in porabo krme. Dodatek medu v pitni vodi za pitovne piščance v skupini $60 \mathrm{H}$ v vročem in sušnem obdobju v vročih in vlažnih tropih je izboljšal nekatere pokazatelje stresa, pitovne lastnosti in povečal relativno maso vranice.

Ključne besede: perutnina; pitovni piščanci; prehrana živali; med; rast; fizološke lastnosti; klavne lastnosti; vroče sušno obdobje

bient temperature and high humidity which have been reported to affect the productive performance of chickens (Ahmad et al., 2005; Daghir, 2008). Great losses are being encountered in broiler production in Nigeria every year due to the effect of heat-stress. The loss is attributed to the fact that the birds have rapid metabolism, high body temperature and no sweat gland (Abioja, 2010).

In South Western Nigeria, environmental temperature is often higher than the recommended temperature of $18-21^{\circ} \mathrm{C}$ (Charles et al., 2002) for optimal productivity of growing broiler chickens particularly during the

1 Federal University of Agriculture, Department of Animal Physiology, PMB 2240, Abeokuta, Nigeria

2 Corresponding author, e-mail: emaoke7@yahoo.co.uk 
dry season which usually occurs between the month of November and March. As a result of this peculiarity, a passable and appropriate measures that can ameliorate the adverse effect of the environmental factors to the barest minimum to ensure optimum broiler production in the hot dry season are essential.

Some of the methods recommended to alleviate the adverse effects of high ambient temperature including housing, ventilation, air conditioning and cooling systems are now issues that are probably applicable on a regional basis (Armstrong et al., 1999; Yalcin et al., 2001). However, some of these methods cannot be applied in developing countries including Nigeria because of their impracticability and high cost. Instead, nutritional manipulation with its low cost is a common approach in poultry production (Austic, 1985; Leeson, 1986; Shane, 1988). Results from various studies (Sayed and Shoeib, 1996; Yahav and McMurty, 2001; Curca et al., 2004; Aradas et al., 2005; Gonzalez-Esquerra and Leeson, 2006; Ramnath et al., 2008; Zhang et al., 2009; Abioja et al., 2011) on several measures taken to abridge the effect of heat stress in poultry with the use of several therapeutic agents remain inconclusive. Moreover, several natural substances that are rich in antioxidants have also been used on heat-stressed chickens. These include bee pollen (Wang et al., 2005), ginger root (Zhang et al., 2009), etc. The use of honey has however received a meagre attention.

Honey is a complex product and contains natural anti-oxidants. Antioxidants play a major role in the protection of cells from reactive oxygen species (ROS) by reducing chemical radicals and preventing the process of lipid peroxidation (Yu, 1994). When compared to synthetic vitamin $\mathrm{C}$ that is conventionally used, honey is more readily available while vitamin $\mathrm{C}$ may not be readily available especially to the local farmers. Honey is a good example of natural substance that contains phytochemicals such as vitamin $\mathrm{C}$, thiamine, riboflavin, pyridoxine, pantothenic acid, nicotinic acid, phenolic compounds, and enzymes glucose oxidase, catalase, and peroxidise. Honey has been used by man for several purposes especially as an antioxidant. However, there is a dearth of reports on the use of h oney in poultry production. Our previous study (Abioja et al., 2010) on the inclusion levels of honey $(0,10,20 \mathrm{ml})$ in drinking water of broiler chickens neither affected the growth nor reduced the body temperature while there was no change in the physiological responses and haematology on adding 0 and $10 \mathrm{ml}$ of honey but slight change in physiological responses occurs on adding $20 \mathrm{ml}$ of honey. Therefore this trial was carried out to determine if an increase in the inclusion levels of honey $(20,40,60 \mathrm{mls})$ in drinking water of broiler chickens from day-old to 8 weeks old would in- fluence more changes in the physiological responses and also bring about the possibility of better performance of broiler chickens. This study therefore aimed at determining the effect of different levels of honey on the physiological response of broiler chicken during hot-dry season

\section{MATERIALS AND METHODS}

\subsection{EXPERIMENTAL SITE}

The experiment was carried out at the poultry unit of Directorate of University Farms (DUFARMS) and the laboratory, Federal University of Agriculture, Abeokuta (FUNAAB). The University is located on latitude $7^{\circ} 10^{\prime} \mathrm{N}$, longitude $3^{\circ} 2^{\prime} \mathrm{E}$ and altitude $76 \mathrm{~m}$ above sea level. It lies between South-Western part of Nigeria with a prevailing tropical climate with a mean annual rainfall of $1,037 \mathrm{~mm}$, and annual mean temperature and relative humidty of $34^{\circ} \mathrm{C}$ and $82 \%$, respectively (Amujoyegbe et al., 2008). The vegetation in the University represents the interphase between the tropical rain forest and the derived savannah. The average maximum and minimum temperature during the period of the experiment was $35.5^{\circ} \mathrm{C}$ and $23.8^{\circ} \mathrm{C}$, respectively while relative humidity was $92 \%$.

\subsection{EXPERIMENTAL ANIMALS AND PROCE- DURE}

Three hundred Oba Marshall broiler day-old chicks purchased from a reputable hatchery at one day of age were used for this study. The brooding temperature was maintained at $35^{\circ} \mathrm{C}$ for the first two days then decreased gradually until 21 days of age. The light regime was 23L: 1D. The vaccination schedule for commercial broiler chickens was followed. The chicks were randomly assigned to five treatment groups with each treatment having four replicates of 15 birds in a completely randomized design at day 21 . The first 4 treatment groups were daily supplied drinking water without honey $(0 \mathrm{H})$, with $20 \mathrm{ml}$ $(20 \mathrm{H}), 40 \mathrm{ml}(40 \mathrm{H})$ and $60 \mathrm{ml}(60 \mathrm{H})$ of honey per liter of water. The fifth group received drinking water supplemented with $500 \mathrm{mg}$ vitamin C per liter of water (C).

The birds were kept on deep-litter floor in an opensided poultry house. The birds were floor-brooded for three weeks on wood-shavings. Additional sources of heat were provided during the brooding period. The chicks were fed ad libitum with standard starter mash and thereafter with finisher mash. Water at ambient temperature was supplied ad libitum throughout the period of the experiment. The composition of the diet is shown in Table 1. 


\subsection{DATA COLLECTION}

\subsubsection{GROWTH PERFORMANCE}

Bodyweight of the birds in each replicate were monitored using a sensitive scale every week during the experiment. Records on daily weight gain (WG) and feed intake (FI) were taken. Feed conversion ratio (FCR) was calculated as the ratio of gain to feed consumed.

\subsubsection{RELATIVE WEIGHTS OF ORGANS}

At 56 days of age, 2 birds per replicate were slaughtered. The birds were dissected and the weights of liver, kidney, lungs, spleen, breast meat, gizzard, drum stick, shank, thigh, tibia, small intestine, proventriculus, ab-

Table 1: Composition of diets for broiler (starter and finisher phases)

Preglednica 1: Sestava popolne krmne mešanice za pitovne piščance (začetna in končna faza pitanja)

\begin{tabular}{lcc}
\hline Ingredient & Starter phase & Finisher phase \\
\hline Maize & 46.00 & 50.00 \\
Soybean meal & 18.50 & 12.00 \\
Groundnut cake & 15.00 & 11.00 \\
Fish meal & 2.00 & 2.00 \\
Wheat offal & 12.45 & 19.05 \\
Bone meal & 2.00 & 2.00 \\
Oyster shell & 3.00 & 3.00 \\
Salt & 0.25 & 0.25 \\
Premix & 0.25 & 0.25 \\
Methionine & 0.30 & 0.25 \\
Lysine & 0.25 & 0.20 \\
& 100 & 100
\end{tabular}

\begin{tabular}{|c|c|c|}
\hline \multicolumn{3}{|l|}{ Calculated } \\
\hline Crude protein (\%) & 23.05 & 19.91 \\
\hline M.E (Kcal/kg) & 2816 & 2809.6 \\
\hline Ether extract (\%) & 3.93 & 3.89 \\
\hline Crude fiber (\%) & 3.67 & 3.79 \\
\hline Calcium (\%) & 1.75 & 1.74 \\
\hline Phosphorus (\%) & 0.43 & 0.41 \\
\hline \multicolumn{3}{|c|}{$\begin{array}{l}\text { * } 1 \mathrm{~kg} \text { of premix contains: Vitamin A - 10,000,000 IU; Vitamin } \\
\text { D3 - 2,000,000; Vitamin E - 20,000 IU; Vitamin K - 2,250 mg; } \\
\text { Thiamine B1 - 1,750 mg; Riboflavin B2 - 5,000 mg; Pyridoxine } \\
\text { B6 - 2,750 mg; Niacin - 27,500 mg; Vitamin B12 - } 15 \mathrm{mg} \text {; Panto- } \\
\text { thenic acid - 7,500 m; Folic acid - 7,500 mg; Biotin - } 50 \mathrm{mg} \text {; Choline } \\
\text { chloride - } 400 \mathrm{~g} \text {; Antioxidant - } 125 \mathrm{~g} \text {; Magnesium - } 80 \mathrm{~g} \text {; Zinc - } \\
50 \mathrm{mg} \text {; Iron - 20 g; Copper - } 5 \text { g; Iodine - } 1.2 \mathrm{~g} \text {; Selenium - } 200 \mathrm{mg} \text {; } \\
\text { Cobalt - } 200 \mathrm{mg}\end{array}$} \\
\hline
\end{tabular}

dominal fat pad, gastrointestinal tract, bursa of Fabricius, thymus, heart were taken and relative weights were determined as a percentage of bird's bodyweights.

\subsubsection{HAEMATOLOGY AND SERUM ANALYSIS}

Blood samples were collected from two randomly picked birds from each replicate once a week via brachial vein into ethylene diamine tetra acetic acid (EDTA) anticoagulant and immediately mixed gently to avoid clotting. Blood samples were analysed for haemoglobin $(\mathrm{Hb})$, Packed Cell Volume (PCV), Total Erythrocyte Count (TEC), Total Leukocyte Count (TLC) and Differential Leukocyte Count (DLC). Hb estimation was determined by cyanmethaemoglobin method and PCV by microhematocrit method (Bernard et al., 2000). TEC and TLC were determined using Neubaur's hemocytometer and Toluidine blue $(0.015 \%)$ saline as diluent (Brar et al., 2002). The blood films stained with Wright's stain (Benjamin, 1985) was studied for DLC. Mean cell volume (MCV), mean corpuscular hemoglobin $(\mathrm{MCH})$, and mean corpuscular hemoglobin concentration (MCHC) were calculated (Stockham and Scott, 2002).

The blood samples were also analyzed for serum metabolites including serum total protein, albumin, globulin and creatinine. Serum glucose was determined colorimetrically using the method described by Braham and Trinder (1969). The total serum protein was determined according to the method of Colowick and Kaplan (1955) while serum albumin and globulin was determined using bromocresol purple method of Varley et al., (1980). Serum corticosterone was determined using radio immunoassay (RIA) technique as described by Darras et al. (1992).

\subsection{STATISTICAL ANALYSIS}

All data collected were subjected to analysis of variance using the procedure of SAS (1999). Significantly different means were compared using Duncan Multiple Range Test.

\section{RESULTS}

\subsection{SERUM CHEMISTRY}

The effect of different levels of honey on serum parameters in broiler chickens at finisher phase during hotdry season is shown in Table 2. The blood glucose level in $0 \mathrm{H}$ and $60 \mathrm{H}$ treatment groups were similar but higher than those birds in $40 \mathrm{H}, 20 \mathrm{H}$ and $\mathrm{C}$ treatment groups. 
Table 2: Effect of different levels of honey on serum parameters of broiler chickens at finisher phase Preglednica 2: Učinek različnih ravni dodajanja medu na parametre krvnega seruma pitovnih piščancev v končnem obdobju pitanja

\begin{tabular}{lcccrrr}
\hline Parameters & $0 \mathrm{H}$ & $20 \mathrm{H}$ & $40 \mathrm{H}$ & $60 \mathrm{H}$ & Vit C & SEM \\
\hline Glucose (mg/dl) & $124.65^{\mathrm{a}}$ & $101.90^{\mathrm{b}}$ & $107.95^{\mathrm{b}}$ & $125.9^{\mathrm{a}}$ & $95.8^{\mathrm{b}}$ & 5.13 \\
Total Protein(g/l) & $52.45^{\mathrm{b}}$ & $52.70^{\mathrm{b}}$ & $58.55^{\mathrm{ab}}$ & $61.15^{\mathrm{a}}$ & $63.65^{\mathrm{a}}$ & 1.62 \\
Albumin (g/l) & 36.05 & 34.55 & 39.45 & 39.05 & 41.10 & 1.20 \\
Globulin (g/l) & 16.40 & 18.15 & 19.10 & 21.60 & 22.55 & 0.99 \\
Triglyceride(mg/dl) & $145.80^{\mathrm{c}}$ & $123.20^{\mathrm{c}}$ & $148.25^{\mathrm{c}}$ & $226.80^{\mathrm{a}}$ & $185.70^{\mathrm{b}}$ & 12.50 \\
AST (IU/l) & $145.80^{\mathrm{a}}$ & $112.45^{\mathrm{b}}$ & $135.60^{\mathrm{ab}}$ & $130.85^{\mathrm{ab}}$ & $140.40^{\mathrm{a}}$ & 4.40 \\
ALT (IU/l) & $36.70^{\mathrm{ab}}$ & $36.40^{\mathrm{ab}}$ & $21.85^{\mathrm{b}}$ & $45.75^{\mathrm{a}}$ & $57.45^{\mathrm{a}}$ & 4.38 \\
Creatine kinase (IU/l) & $129.15^{\mathrm{ab}}$ & $107.90^{\mathrm{cd}}$ & $136.15^{\mathrm{a}}$ & $119.35^{\mathrm{bc}}$ & $100.00^{\mathrm{d}}$ & 4.63 \\
Corticosterone (ng/mL) & $237.50^{\mathrm{a}}$ & $157.00^{\mathrm{c}}$ & $198.50^{\mathrm{b}}$ & $203.50^{\mathrm{b}}$ & $189.50^{\mathrm{b}}$ & 8.75 \\
\hline
\end{tabular}

${ }^{a, b, c}$ Means within a row with different superscripts differ significantly $(p<0.05)$. AST - Aspartate amino-transferase; ALT - Alanine amino-transferase

Moreover, birds on $40 \mathrm{H}, 20 \mathrm{H}$ and $\mathrm{C}$ had also similar blood glucose levels. The level of total protein in the birds in $\mathrm{C}$ and $60 \mathrm{H}$ treatment groups were similar but significantly higher $(p<0.05)$ than in birds in $20 \mathrm{H}$ and $0 \mathrm{H}$ treatments while those of $40 \mathrm{H}, 20 \mathrm{H}$ and $0 \mathrm{H}$ were similar. The triglyceride level of $60 \mathrm{H}$ was significantly higher than those of other treatment groups. Birds in $40 \mathrm{H}, 0 \mathrm{H}, 20 \mathrm{H}$ treatment groups had similar level of triglyceride but lower than that of $\mathrm{C}$ treatment group. Birds in $\mathrm{OH}$ and $\mathrm{C}$ treatment group were similar but higher in aspartate amino-transferase level than those of the birds in $20 \mathrm{H}$. Birds in $\mathrm{C}$ and $60 \mathrm{H}$ treatment group were higher in alanine amino-transferase level than those of $40 \mathrm{H}$ treatment group. Also $0 \mathrm{H} 20 \mathrm{H}, 60 \mathrm{H}$ and $\mathrm{C}$ treatment groups were similar in alanine aminotransferase levels. Creatine kinase level in $40 \mathrm{H}$ was significantly higher than those of other treatment groups apart from the birds in $\mathrm{OH}$ which had similar levels. Birds in $\mathrm{C}$ treatment group had similar level of creatine kinase than those in $20 \mathrm{H}$ but lower than the birds in the other treatment groups. Birds in $\mathrm{OH}$ had a significantly higher level of creatinine kinase than those of $20 \mathrm{H}$ and $\mathrm{C}$ treatment groups. Birds in $0 \mathrm{H}$ had higher $(p<0.05)$ level of serum corticosterone than those of the other treatment groups. The level of serum corticosterone recorded in the birds in $20 \mathrm{H}$ treatment group was lower $(p<0.05)$ than those of $0 \mathrm{H}, 60 \mathrm{H}, 40 \mathrm{H}$ and $\mathrm{C}$ treatment group.

Table 3: Effect of different levels of honey on haematological parameters of broiler chickens at finisher phase during hot-dry season Preglednica 3: Učinek dodajanja medu na hematološke parametre pitovnih piščancev v končni fazi pitanja $v$ vročem in suhem obdobju

\begin{tabular}{|c|c|c|c|c|c|c|}
\hline \multirow[b]{2}{*}{ Parameters } & \multicolumn{5}{|c|}{ Level of honey and vitamin C } & \multirow[b]{2}{*}{ SEM } \\
\hline & $0 \mathrm{H}$ & $20 \mathrm{H}$ & $40 \mathrm{H}$ & $60 \mathrm{H}$ & Vit C & \\
\hline PCV $(\%)$ & 30.50 & 27.50 & 32.00 & 32.50 & 37.00 & 1.57 \\
\hline Haemoglobin (G/Dl) & 9.85 & 8.80 & 10.55 & 10.20 & 11.35 & 0.44 \\
\hline Red blood cell & 2.60 & 2.30 & 2.75 & 2.80 & 3.15 & 0.15 \\
\hline White blood cell & 10.85 & 10.20 & 11.20 & 10.00 & 9.80 & 0.29 \\
\hline Heterophil & 30.00 & 32.00 & 36.50 & 30.50 & 35.50 & 1.80 \\
\hline Lymphocyte (\%) & 70.00 & 66.00 & 63.50 & 68.50 & 63.50 & 1.85 \\
\hline Eosinophil (\%) & 0.00 & 0.50 & 0.00 & 0.00 & 0.50 & 0.13 \\
\hline Basophil (\%) & 0.00 & 0.50 & 0.00 & 0.00 & 0.00 & 0.10 \\
\hline Monocyte (\%) & 0.00 & 1.00 & 0.00 & 1.00 & 0.50 & 0.27 \\
\hline HL & 0.43 & 0.51 & 0.58 & 0.45 & 0.56 & 0.04 \\
\hline $\mathrm{MCH}(\mu \mu \mathrm{G})$ & 38.03 & 38.18 & 38.26 & 37.13 & 36.32 & 0.95 \\
\hline $\operatorname{MCV}\left(\mu^{3}\right)$ & 117.85 & 119.31 & 116.39 & 117.25 & 118.21 & 2.64 \\
\hline MCHC (\%) & 32.33 & 32.00 & 32.87 & 31.61 & 30.70 & 0.35 \\
\hline
\end{tabular}

MCV - Mean corpuscular volume, MCH - Mean corpuscular haemoglobin, MCHC - Mean Corpuscular haemoglobin concentration, HL - Heterophil : lymphocyte ratio, PCV - Packed cell volume 
Table 3 shows the effect of different levels of honey on haematological parameters of broiler chickens at finisher phase during the hot-dry season. There was no significant effect of different levels of honey on the haematological parameters of the birds among the treatment groups at the finisher phase.

\subsection{GROWTH PERFORMANCE}

Effect of different levels of honey on the performance of broiler chickens is presented in Table 4 . The weight gain of the birds in $60 \mathrm{H}$ treatment group was higher than those of the birds in the other treatment groups. The birds in $20 \mathrm{H}$ treatment group had similarweight gains as those of $40 \mathrm{H}$ and $\mathrm{C}$ groups. The weight gain in $\mathrm{OH}$ was lower than those of the other treatment groups. Also the feed intake of the birds in $0 \mathrm{H}$ was lower than those of the other treatment groups whose values were similar. The feed conversion ratio was similar across the treatment groups $(p>0.05)$.

\subsection{RELATIVE WEIGHTS OF ORGANS}

Effect of different levels of honey on the relative weights of organs of broiler chickens is presented in $\mathrm{Ta}$ ble 5 . The body weights of the birds in $20 \mathrm{H}$ and $40 \mathrm{H}$ were significantly higher $(p<0.05)$ than that of $\mathrm{OH}$ group. The weights of the birds in $60 \mathrm{H}$ and $\mathrm{C}$ group were similar but higher than the weights recorded in the other treatment groups. The relative weights of liver in broiler chickens in $0 \mathrm{H}$ group were significantly higher $(p<0.05)$ than those of other treatment groups. The liver relative weights of the birds in $40 \mathrm{H}$ goup were higher than those of $20 \mathrm{H}$, $60 \mathrm{H}$ and $\mathrm{C}$ group. The relative weights of kidney of the birds in $40 \mathrm{H}, 60 \mathrm{H}$ and $\mathrm{C}$ group were similar but significantly higher $(p<0.05)$ than those of $0 \mathrm{H}$ and $20 \mathrm{H}$. The relative weight of the lungs of the birds in $0 \mathrm{H}$ was sig- nificantly higher than those of other treatment groups. The heart weights of the birds in $0 \mathrm{H}$ group were significantly higher $(p<0.05)$ than those of the other treatment groups. The relative weight of small intestine in broiler chicken of $0 \mathrm{H}$ group was significantly higher $(p<0.05)$ than those of the other treatment groups. The birds in $40 \mathrm{H}$ group had a significantly higher $(p<0.05)$ weights than those of $60 \mathrm{H}$ and $\mathrm{C}$ treatment groups. The relative weight of proventriculus of the birds in $0 \mathrm{H}$ group was significantly higher $(p<0.05)$ than those of the other treatment groups. The relative weights of empty gizzard in $60 \mathrm{H}$ and $\mathrm{C}$ group were similar but significantly higher $(p<0.05)$ than that of $40 \mathrm{H}$ group whose value was also higher than that of $20 \mathrm{H}$ group. The relative weights of breast meat of the birds in $20 \mathrm{H}$ and $40 \mathrm{H}$ group were similar but significantly higher $(p<0.05)$ than those of $0 \mathrm{H}$, $60 \mathrm{H}$ and $\mathrm{C}$ treatment groups whose values were similar. The relative weight of thigh in $0 \mathrm{H}$ group was significantly higher $(p<0.05)$ than those of the other treatment groups. The values recorded for the birds in $40 \mathrm{H}$ were higher than those of the birds in $60 \mathrm{H}$ and $\mathrm{C}$ treatment groups whose values were similar. The shank relative weight recorded in the birds in $60 \mathrm{H}$ was higher than in those of the other treatments. The drum stick weight was also higher in the birds in $60 \mathrm{H}$ than the birds in the other treatment groups. The value for $40 \mathrm{H}$ was also higher than those of $0 \mathrm{H}$ and $\mathrm{C}$ treatment groups. The GIT relative weights recorded in the birds in $60 \mathrm{H}$ were higher than those of the other treatment groups. The values in $20 \mathrm{H}$ and $40 \mathrm{H}$ were comparable but higher than those of $0 \mathrm{H}$ and $\mathrm{C}$ treatment groups.

The relative weights of tibia in $40 \mathrm{H}$ were comparable to those of $60 \mathrm{H}$ and $\mathrm{C}$ treatment groups but significantly higher $(p<0.05)$ than those of $0 \mathrm{H}$ and $20 \mathrm{H}$ groups, which were similar to those of $60 \mathrm{H}$ and $\mathrm{C}$ treatment groups.

Effect of different levels of honey on the relative weights of lymphoid organs of broiler chickens at finisher phase during hot-dry season is presented in Table 6. The relative weight of thymus of the birds in $40 \mathrm{H}$ was similar

Table 4: Effect of different levels of honey on performance of broiler chickens at finisher phase

Preglednica 4: Učinek različnih ravni dodanega medu na proizvodne lastnosti pitovnih piščancev v končni fazi pitanja

\begin{tabular}{lcccrrr}
\hline & \multicolumn{2}{l}{ Levels of inclusion honey } & & & \\
\cline { 2 - 5 } Parameters & $0 \mathrm{H}$ & $20 \mathrm{H}$ & $40 \mathrm{H}$ & $60 \mathrm{H}$ & Vit C & SEM \\
\hline Initial body weight at 4wks (g) & 590.52 & 588.28 & 586.69 & 585.41 & 587.96 & 2.04 \\
Final body weight (g) & $1785.10^{\mathrm{d}}$ & $1839.44^{\mathrm{c}}$ & $1855.45^{\mathrm{b}}$ & $1887.62^{\mathrm{a}}$ & $1828.36^{\mathrm{c}}$ & 7.89 \\
Weight gain (g) & $1194.59^{\mathrm{d}}$ & $1251.16^{\mathrm{bc}}$ & $1268.76^{\mathrm{b}}$ & $1302.21^{\mathrm{a}}$ & $1240.42^{\mathrm{c}}$ & 8.59 \\
Feed intake (g) & $2783.10^{\mathrm{b}}$ & $2992.05^{\mathrm{a}}$ & $2973.93^{\mathrm{a}}$ & $3028.06^{\mathrm{a}}$ & $2963.39^{\mathrm{a}}$ & 26.00 \\
Feed conversion ratio & 2.32 & 2.39 & 2.34 & 2.32 & 2.39 & 0.01 \\
Mortality & 0 & 0 & 0 & 0 & 0 & \\
\hline
\end{tabular}

a, b, c, d Means within rows with different superscripts differ significantly $(p<0.05)$ 
Table 5: Effect of different levels of honey on the relative weight of organs of broiler chickens at finisher phase during hot-dry season Preglednica 5: Učinek dodajanja različnih količin medu na relativno maso organov pitovnih piščancev v končni fazi pitanja v vročem in suhem obdobju

\begin{tabular}{|c|c|c|c|c|c|c|}
\hline \multirow[b]{2}{*}{ Parameters } & \multicolumn{5}{|c|}{ Level of honey and vitamin $\mathrm{C}$} & \multirow[b]{2}{*}{ SEM } \\
\hline & $0 \mathrm{H}$ & $20 \mathrm{H}$ & $40 \mathrm{H}$ & $60 \mathrm{H}$ & Vit C & \\
\hline Body weight (kg) & $1.70^{c}$ & $2.03^{\mathrm{b}}$ & $2.05^{\mathrm{b}}$ & $2.25^{\mathrm{a}}$ & $2.35^{\mathrm{a}}$ & 0.077 \\
\hline Liver (\%) & $2.60^{\mathrm{a}}$ & $2.03^{\mathrm{c}}$ & $2.27^{\mathrm{b}}$ & $2.11^{\mathrm{c}}$ & $2.05^{\mathrm{c}}$ & 0.072 \\
\hline Kidney (\%) & $0.12^{\mathrm{b}}$ & $0.14^{\mathrm{b}}$ & $0.16^{\mathrm{a}}$ & $0.16^{\mathrm{a}}$ & $0.16^{\mathrm{a}}$ & 0.006 \\
\hline Lungs (\%) & $0.54^{\mathrm{a}}$ & $0.51^{\mathrm{b}}$ & $0.49^{\mathrm{bc}}$ & $0.48^{\mathrm{cd}}$ & $0.46^{\mathrm{d}}$ & 0.010 \\
\hline Heart (\%) & $0.72^{\mathrm{a}}$ & $0.42^{\mathrm{b}}$ & $0.43^{\mathrm{b}}$ & $0.46^{\mathrm{b}}$ & $0.46^{\mathrm{b}}$ & 0.038 \\
\hline Small intestine (\%) & $3.08^{\mathrm{a}}$ & $2.73^{\mathrm{bc}}$ & $2.87^{\mathrm{b}}$ & $2.66^{\mathrm{cd}}$ & $2.55^{\mathrm{d}}$ & 0.062 \\
\hline Proventriculus (\%) & $2.66^{\mathrm{a}}$ & $2.39^{\mathrm{b}}$ & $2.44^{\mathrm{b}}$ & $2.25^{\mathrm{c}}$ & $2.17^{\mathrm{c}}$ & 0.058 \\
\hline Empty gizzard (\%) & $0.25^{\mathrm{d}}$ & $2.14^{\mathrm{c}}$ & $2.31^{\mathrm{b}}$ & $2.44^{\mathrm{a}}$ & $2.43^{\mathrm{a}}$ & 0.280 \\
\hline Abdominal fat (\%) & 1.62 & 1.58 & 1.69 & 1.63 & 1.58 & 0.018 \\
\hline Breast meat (\%) & $17.76^{\mathrm{b}}$ & $19.10^{\mathrm{a}}$ & $19.15^{\mathrm{a}}$ & $17.61^{\mathrm{b}}$ & $16.95^{\mathrm{b}}$ & 0.312 \\
\hline Thigh (\%) & $18.88^{\mathrm{a}}$ & $9.15^{\mathrm{d}}$ & $12.23^{\mathrm{b}}$ & $11.17^{\mathrm{c}}$ & $10.72^{\mathrm{c}}$ & 1.129 \\
\hline Shank (\%) & $2.73^{\mathrm{b}}$ & $2.74^{\mathrm{b}}$ & $2.95^{\mathrm{b}}$ & $5.08^{\mathrm{a}}$ & $2.648^{\mathrm{b}}$ & 0.312 \\
\hline Drum stick (\%) & $4.53^{\mathrm{cd}}$ & $4.74^{\mathrm{bc}}$ & $4.93^{\mathrm{b}}$ & $5.65^{\mathrm{a}}$ & $4.35^{\mathrm{d}}$ & 0.153 \\
\hline Tibia (\%) & $0.788^{\mathrm{b}}$ & $0.803^{\mathrm{b}}$ & $0.94^{\mathrm{a}}$ & $0.88^{\mathrm{ab}}$ & $0.87^{\mathrm{ab}}$ & 0.020 \\
\hline GIT (\%) & $15.505^{c}$ & $16.66^{\mathrm{b}}$ & $16.92^{\mathrm{b}}$ & $18.85^{\mathrm{a}}$ & $14.93^{\mathrm{c}}$ & 0.463 \\
\hline
\end{tabular}

${ }^{a, b, c}$ Means within a row with different superscripts differ significantly $(p<0.05)$

to that of $60 \mathrm{H}$ but significantly higher than those of $20 \mathrm{H}$, $0 \mathrm{H}$ and $\mathrm{C}$ treatment groups. However the relative weights of thymus in broiler chicken of $0 \mathrm{H}, 20 \mathrm{H}$ and $\mathrm{C}$ treatment groups were similar. The relative weights of spleen of the birds in $40 \mathrm{H}, 60 \mathrm{H}$ and $\mathrm{C}$ group were similar but significantly higher $(p<0.05)$ than that of $0 \mathrm{H}$ and $20 \mathrm{H}$. The weights recorded in the birds in $20 \mathrm{H}$ were significantly higher $(p<0.05)$ than that of $0 \mathrm{H}$.

\section{DISCUSSION}

Enhanced levels of serum ALT, AST and LDH are used as indicators of liver damage (Ozaki et al., 1995). In the present study, the activity of AST and ALT enzymes did not follow a consistent trend with the inclusion of honey in the drinking water of broilers during stress. This supports the findings of Hosseini-Vashan et al. (2012) who reported that turmeric powder depressed AST in heat stressed broiler due to the antioxidant curcumin which is a component of the additive. The similarity in levels of serum albumin and globulin in the birds offered different levels of honey and ascorbic acid in the present study differs from the findings of Al-Shanti (2005) who found that supplementing heat stressed broilers with $1 \mathrm{~g}$ vitamin $\mathrm{C} / \mathrm{l}$ drinking water had no effect on blood albumin and globulin

The present study showed that inclusion of honey at

Table 6: Effect of different levels of honey on the relative weight of lymphoid organs of broiler chickens at finisher phase during hot-dry season

Preglednica 6: Učinek dodajanja različnih količin medu na relativno maso limfatičnih organov pitovnih piščancev $v$ končni fazi pitanja $v$ vročem in suhem obdobju

\begin{tabular}{lllllll}
\hline & \multicolumn{4}{l}{ Level of honey and vitamin C } & & \\
Marameters & $0 \mathrm{H}$ & $20 \mathrm{H}$ & $40 \mathrm{H}$ & $60 \mathrm{H}$ & Vit C & SEM \\
\hline Spleen (\%) & $0.017^{\mathrm{c}}$ & $0.029^{\mathrm{b}}$ & $0.038^{\mathrm{a}}$ & $0.383^{\mathrm{a}}$ & $0.039^{\mathrm{a}}$ & 0.075 \\
Thymus (\%) & $3.082^{\mathrm{bc}}$ & $3.867^{\mathrm{b}}$ & $4.019^{\mathrm{a}}$ & $3.882^{\mathrm{ab}}$ & $3.831^{\mathrm{b}}$ & 0.035 \\
Bursa (\%) & 0.560 & 0.545 & 0.576 & 0.562 & 0.553 & 0.005 \\
\hline
\end{tabular}

${ }^{a, b, c}$ Means within a row with different superscripts differ significantly $(p<0.05)$ 
$60 \mathrm{ml} / \mathrm{l}$ improved the total serum protein. Similar reports were obtained by Giurgea et al. (1981) who indicated that daily administration of propolis extract to chickens had a significant effect on the serum. On the contrary, Al-Shanti (2005) reported that supplementing vitamin C to the heat-stressed broilers had no effect on blood total protein. This may be due to the difference in the strains of the birds used for the experiment. The decrease in the serum glucose levels of the birds offered honey at 20 and $40 \mathrm{ml} / \mathrm{l}$ and vitamin Cin this trial corroborates the findings of Hazim et al. (2001) who reported an improvement in the blood glucose level of broiler birds whose diets were supplemented with ascorbic acid (at 0, 150, 300 and $450 \mathrm{mg} / \mathrm{kg}$ diet) during summer months.

The creatine kinase levels of the birds offered honey was not elevated comapred with the birds offered ordinary water in this study. The lower levels observed in the birds offered $20 \mathrm{ml} / \mathrm{l}$ and vitamin $\mathrm{C}$ in the present study may indicate that honey supplementation did not impair the function of the kidney. Also the corticosterone levels of broiler chickens supplemented with honey were lower than in the $0 \mathrm{H}$ group. This suggests that addition of honey up to $60 \mathrm{H}$ helped in ameliorating heat stress in broiler chickens compared to $0 \mathrm{H}$ group. This is in agreement with previous studies (Mckee and Hurrison, 1995; Mahmoud et al., 2004) which reported that the improved performance resulting from the use of ascorbic acid was associated with the suppressed stress response indicated by reduction in plasma corticosterone level. Stressors such as high environmental temperature induce a cascade of neural and hormonal events, beginning with hypothalamic stimulation and the production of corticotrophinreleasing factor, which stimulates the anterior pituitary to produce adrenocorticotropic hormone, and ending with stimulation of adrenal cortical tissue by adrenocorticotropic hormone to increase the production and release of corticosteroids, primarily corticosterone in birds (Siegel, 1995). The reduction in the levels of serum corticosterone in birds offered varying levels of honey in this study, implies that addition of honey in the drinking water of broiler chickens had an ameliorative effect on the birds and they were able to cope with the hot dry season and to perform better than the birds in the control group.

The higher body weights recorded in the birds in $60 \mathrm{H}$ in the present study are in conformity with the report of Gross (1988) who reported that dietary vitamin $\mathrm{C}$ improved growth performance in broilers. The higher weights of birds associated with higher dosage of honey beyond $20 \mathrm{ml}$ in this study suggest that this level contained potent antioxidant which was beneficial to the birds during stress. The present observation is an improvement on our previous findings (Abioja et al., 2010) where it was reported that there was no significant differ- ence in the weights of broiler chickens offered honey up to $20 \mathrm{ml} / \mathrm{l}$ in drinking water. This could therefore be explained by the fact the doses of honey $(20 \mathrm{ml} / \mathrm{l}$ of water $)$ administered in the previous study was not high enough to cause a positive effect. The higher feed intake observed in the birds offered dietary vitamin $\mathrm{C}$ and honey in the present study corresponds to the report of Bonomi et al. (1976) who found an increase in feed intake when propolis was fed to laying hens.

Addition of honey to the drinking water of heatstressed birds had no significant effect on PCV, RBC, WBC, heterophil, lymphocyte, eosinophil, monocyte, basophil, MCH, MCV, MCHC, haemoglobin and HL. The PCV values of all the experimental birds were within the normal range for chickens (24.9-45.2\%) as reported by Mitruka et al. (1997). Also all HB, MCV, MCH and $\mathrm{MCHC}$ values of all experimental birds were within the normal range for chickens (7-13, 90-140, 33-47 and 26-35, respectively).

This study has shown that relative weights of tibia were improved by addition of honey to the drinking water of broiler chickens especially at high dose $(40 \mathrm{H})$. This might be adduced to the improvement in calcium metabolism of the birds. The higher relative weight of the tibiae is concurrent with the findings of Abioja et al. (2012) who observed that addition of honey up to $20 \mathrm{ml} / \mathrm{l}$ of water for broiler chickens improved tibiae weight. The present study has further validated the fact that a dose higher than $20 \mathrm{ml} / \mathrm{l}$ is beneficial to the birds during hot dry season in Nigeria.

The relative weight of thymus was increased by the addition of $40 \mathrm{ml}$ honey/l of water. Heat stress has been reported to inhibit immune functions in chickens (Curca et al. (2003); Mashaly et al. (2004). Surgical removal of thymus has been used to demonstrate its immunologic role (Panigraphi et al., 1971). Efficacy of Sb-Asper-C, a combined ascorbic acid and acetylsalicylic acid treatment in reducing the effects of heat stress was tested in broilers by Anwar et al. (2004). The authors reported that the treatment increased the ratio of thymus to body weight. The thymus of heat-stressed chickens not supplemented with $\mathrm{Sb}$-Asper-C was atrophied. The increase in the thymus in the present study supports the findings of Abioja et al. (2012) that honey up to $20 \mathrm{ml}$ per liter of water reduces the effect of heat stress on thymus.

Increased liver weight has been regarded as one of the indices of stress conditions (Puvadolpirod and Thaxton, 2000). The reduced liver relative weights observed in the birds offered honey in the present study points to the fact that the antioxidant content in the honey used in this study was potent enough to cause change in stress resistancy. The similarity in the relative liver weights of 
the birds offered vitamin $\mathrm{C}$ and honey is an indication that the use of honey can replace vitamin $\mathrm{C}$ during stress.

The gastrointestinal tract is responsive to stressors (Collins et al., 2012; Dinan and Cryan, 2012). The higher gastrointestinal relative weights of the birds that were offered honey in this study suggests that inclusion of honey in the water of the birds ameliorated the effects of heat stress on birds. This is in accordance with the findings of Mitchell and Carlisle (1992) who reported that heat stress lowered the wet and dry weight of small intestine. Moreover, $\mathrm{Hu}$ et al. (2010) also reported that administration of corticosterone lowered small intestinal weight and shortened small intestinal length in broiler chickens.

\section{CONCLUSIONS}

Addition of $20 \mathrm{H} / \mathrm{l}$ of drinking water for broilers may be useful in ameliorating effects of heat stress as it improved some stress indices (serum glucose, corticosterone and creatine kinase), feed intake, body weight gain and mass of lymphoid organ (spleen). The present study has also shown that the use of honey may serve as an antioxidant for the replacement of vitamin $\mathrm{C}$ during stress conditions.

\section{REFERENCES}

Abioja, M. O., Osinowo O. A., Smith O. F., Eruvbetine, D., \& Abiona J. A. (2011). Evaluation of cold water and vitamin C on broiler growth during hot-dry season in south-western Nigeria. Archivos De Zootecnia, 60, 1095-1103. doi:10.4321/ S0004-05922011000400025

Abioja, M. O. (2010). Monthly fertility and hatchability of breeder hens and effects of vitamin $\mathrm{C}$ and chilled water on broiler growth, panting and rectal temperature. Thesis, 144-145.

Abioja, O. M., Ogundimu, K. B., Akibo, T. E., Odukoya, K. E., Ajiboye, O. O., Abiona, J. A., Williams, T. J., Oke, O. E., \& Osionowo, A. O. (2012). Growth, Mineral Deposition, and Physiological Responses of Broiler Chickens Offered Honey in Drinking Water during Hot-Dry Season. International Journal of zoology, Article ID 403502, pp. 6. doi:10.1155/2012/403502

Ahmad, T., Sarwar M., Un-Nisa M., Ul-Haq A., \& Ul-Hasa, Z. (2005). Influence of varying sources of dietary electrolytes on the performance of broilers reared in a high temperature environment. Animal Feed Science Technology, 20, 277-298. doi:10.1016/j.anifeedsci.2005.02.028

Al-Shanti, H. A. (2005). The effect of adding vitamin C, potassium chloride and sodium bicarbonate to the water on the performance of broiler chicks under Palestinian summer conditions. Agricultural Science, 17, 63-73.

Amujoyegbe, B. J., Bamire, A. S., \& Elemo, K. O. (2008). Agronomic Analysis of Fertilizer Effect on Maize/Cowpea Inter- crop in Ile-Ife and Abeokuta, South-Western Nigeria. Asset, Series A, 8, 62-72.

Anwar B., Khan S. A., Maqbool, A., \& Khan K. A. (2004). Effects ofascorbic acid and acetylsalicylic acid supplementation on the performance of broiler chicks exposed to heat stress. Pakistan Veterinary Journal, 24, 109-111.

Aradas, M. E. C., Naas, I. A., \& Salgado, D. D. (2005). Comparing thermal environment in broiler housing using two bird's densities under tropical conditions. Agricultural EngineeringInternational, 7, 1-9.

Armstrong, D. V., Hillman, P. E., Meyer, M. J., Smith, J. F., Stokes, S. R., \& Harner, J. P. (1999). Heat stress management in freestall barns in the western U. S. In Proc. West. Dairy Manage. Conf., Las Vegas, NV (pp. 87-98). Kansas State University Agricultural Experiment Station and Cooperative Extension Service, Manhattan.

Austic, R. E. (1985). Feeding poultry in hot and cold climates. In M. K. Yousef (Ed.), Stress Physiology in Livestock (Vol. 3., pp. 123-136). Boca Raton, FL: CRC Press.

Benjamin, M. M. (1985). Outline of veterinary clinical pathology ( $3^{\text {rd }}$ ed.). Ames: The Iowa State Uni. Press.

Bernard, F. F., Joseph, G. Z., \& Jain, N. C. (2000). Schalm's Veterinary Hematology $\left(5^{\text {th }}\right.$ ed.). Philadelphia: Lippincott Williems and Wilkins.

Bonomi, A., Morletto, F., \& Binachi, M. (1976). Propolis in feeds for laying hens. Avicoltura, 54, 43-54.

Brar, R. S., Sandhu, H. S., \& Singh, A. (2002) Veterinary clinical diagnosis by laboratory methods ( $1^{\text {st }}$ ed.). New Delhi: Kalyani Publishers.

Charles, D. R. (2002). Responses to the thermal environment. In D. A. Charles, \& A. W. Walker (Eds.), Poultry environment problems, a guide to solutions (pp. 1-16). Nottingham, U. K.: Nottingham Univ. Press.

Collins, S. M., Surette, M., \& Bercik, P. (2012). The interplay between the intestinal microbiota and the brain. Nature Reviews Microbiology, 10, 735-742. doi:10.1038/nrmicro2876

Colowick, S. P., \& Kaplan, N. O. (1995). Method of enzymology ( $2^{\text {nd }}$ ed., p. 104). New York: Academic press.

Curca, D., Andronie, V., Andronie I. C., \& Pop, A. (2004). The influence of feed supplementation with acid ascorbic and sodium ascorbate on broilers, under thermal stress. Book of abstracts of XXII World's Poult. Congress WPSA, Istanbul, Turkey, 290.

Daghir, N. J. (2008). Poultry Production in Hot Climates ( $2^{\text {nd }}$ ed., p. 387). Wallinford, Oxfordshire, UK: CAB International. doi:10.1079/9781845932589.0000

Darras, V. M., Visser, T. J., Berghman, L. R., \& Kuhn, E. R. (1992). Ontogeny of type I and type III deiodinase activities in embryonic and posthatch chicken: relationship with changes in plasma triiodothyronine and growth hormone levels. Comparative Biochemistry and Physiology, 103A, 131-136. doi:10.1016/0300-9629(92)90252-L

Dinan, T. G. \& Cryan, J. F. (2012). Regulation of the stress response by the gut microbiota: Implications for psychoneuroendocrinology. Psychoneuroendocrinology, 37(9), 13691378. doi:10.1016/j.psyneuen.2012.03.007

Duncan, D. B. (1995). Multiple Range and F tests. Biometrics, 11, 1-42. doi: $10.2307 / 3001478$

Giurgea, R. Toma, V., Popesv, H., \& Polinicencv, C. (1981). Ef- 
fect of standardized propolis extracts on certain blood constituents in chickens. Glujul Med, 54, 151-4.

Gonzalez-Esquerra, R., \& Leeson, S. (2006). Physiological and metabolic responses of broilers to heat implications for protein and amino acid nutrition. World's poultry Science Journal, 62, 282-295. doi:10.1079/WPS200597

Gross, W. B. (1988). Effects of ascorbic acid on the mortality of leghorn-type chickens due to over-heating. Avian Diseases, 32, 561-562. doi: 10.2307/1590930

Hazim, J., Al-Daraji, Al-Mashhadani, E. H., \& Al-Athari, A. K. (2001). Effect of ascorbic acid supplementation in the diets on haematological traits of Fawbro broiler breeders reared under hot climate. Indian Journal of Animal Science, 71(9), 857-859.

Hosseini-Vashan, S. J., Golian, A., Yaghobfar, A., Zarban, A. Afzali, N., \& Esmaeilinasab, P. (2012). Antioxidant status, immune system, blood metabolites and carcass characteristic of broiler chickens fed turmeric rhizome powder under heat stress. African Journal of Biotechnology, 11, 1611816125. doi:10.5897/AJB12.1986

Hu, X. F., Guo, Y. M., Huang, B. Y., Zhang, L. B., Bun, S., Liu, D., ... Jiao, P. (2010). Effect of Corticosterone Administration on Small Intestinal Weight and Expression of Small Intestinal Nutrient Transporter mRNA of Broiler Chickens. Asian-Australian Journal Animal Science, 23, 175-181. doi:10.5713/ajas.2010.90281

Leeson, S. (1986). Nutritional considerations of poultry during heat stress. World's Poultry Science Journal, 42, 69-81. doi:10.1079/WPS19860007

Mahmoud, K. Z., Edens, F. W., Eisen, E. J., \& Havenstein, G. B. (2004). Ascorbic acid decreases heat shock protein 70 and plasma corticosterone response in broilers (Gallus domesticus) subjected to cyclic heat stress. Comparative Biochemistry and Physiology B, 137, 35-42. doi:10.1016/j. cbpc.2003.09.013

Mckee, J. S., \& Hurrison, P. C. (1995). Effects of supplemental ascorbic acid on the performance of broiler chickens exposed to multiple concurrent stressors. Poultry Science, 74, 1772-1785. doi:10.3382/ps.0741772

Mitchell, M. A., \& Carlisle, A, J. (1992). The effect of chronic exposure to elevated environmental temperature on intestinal morphology and nutrient absorption in the domestic fowl (Gullus domesticus). Comparative Biochemistry and Physiology, 101A, 137-142. doi:10.1016/0300-9629(92)90641-3

Mitruka, B. M., Rawnsley, H. M., \& Vadehra, B. V. (1997). Clinical, biochemical and haematological reference values in normal experimental animals (p. 272). Masson Publishing USA Inc.

Ozaki, M., Fuchinoue, S., Teraoda, S., \& Ota K. (1995). The in vivo cytoprotection of ascorbic acid against ischemia/reoxygenation injury of rat liver. Archive of Biochemistry and Biophysis, 318, 439-445. doi:10.1006/abbi.1995.1252
Puvadolpirod, S., \& Thaxton, J. P. (2000). Model of physiological stress in chickens 1 . Response parameters. Poultry Science, 79, 363-369. doi:10.1093/ps/79.3.363

Ramnath V., Rekha P. S., \& Sujatha, K. S. (2008). Amelioration of heat stress induced disturbances of antioxidant defense system in chicken by Brahma Rasayana. Evidence-Based Complementary and Alternative Medicine, 5(1), 77-84. doi:10.1093/ecam/nel116

Richards, M. P., Poch, S. M., Coon, C. N., Rosebrough, R. W., Ashwell, C. M., \& Mcmurtry, J. P. (2003). Feed restriction significantly alters lipogenic gene expression in broiler breeder chickens. Journal of Nutrition, 133, 707-715.

Sayed, A. N., Shoeib, H. A. (1996). Rapid two weeks evaluation of vitamin $\mathrm{C}$ and B-complex and sodium chloride for heat stressed-stressed broilers. Assiut Veterinary Medical Journal, 34, 37-42.

Shane, S. M. (1988). Factors influencing health and performance of poultry in hot climates. Crit. Rev. Poultry Biolology, 1, 247-267.

Siegel, H. S. (1995). Stress, strains and resistance. British Poultry Science, 36, 3-22. doi:10.1080/00071669508417748

Stockham, S. L., \& Scott, M. A. (2002). Fundamentals of veterinary clinical pathology. Iowa: Iowa State Press, A Blackwell Publishing Company.

Trinder, P. (1969). Determination of glucose in blood using glucose oxidase with an alternative oxygen acceptor. Annals of Clinical Biochemistry, 6, 24-27. doi:10.1177/000456326900600108

Varley, H., Gowelock, A. H., \& Bells, M. (1980). Detemination of serum urea using the acetyl monoxide method. Practical biochemistry ( $5^{\text {th }}$ ed.). London: William Heinemann Medical Books Ltd.

Wang, J., Jin, G. M., Zheng, Y. M., Li, S. H., \& Wang, H. (2005). Effect of bee pollen on development of immune organ of animal. Zhongguo Zhong Yao Za Zhi, 30, 1532-1536.

Yahav, S. Mcmurtry, J. P. (2001). Thermotolerance acquisition in broiler chickens by temperature conditioning early in life - the effect of timing and ambient temperature. Poultry Science, 80, 1662-1666. doi:10.1093/ps/80.12.1662

Yalcin, S., Ozkan, S., Turkmut, L., \& Siegel P. B. (2001). Responses to heat stress in commercial and local broiler stocks. 1. Performance traits. British Poultry Science, 42, 149-152. doi:10.1080/00071660120048375

Yu, B. P. (1994). Cellular defence against damage from reactive oxygen species. Physiological Review, 74, 139-162.

Zhang G. F., Yang Z. B., Wang Y., Yang W. R., Jiang S. Z., \& Gai G. S. (2009). Effects of ginger root (Zingiber officinale) processed to different particle sizes on growth performance, antioxidant status, and serum metabolites of broiler chickens. Poultry Science, 88, 2159-2166. doi:10.3382/ps.200900165 